EDUKACJA MIĘDZYKULTUROWA

2013, nr 2

ISSN 2299-4106

JERZY NIKITOROWICZ

\title{
III Międzynarodowa Konferencja poświęcona dziedzictwu i problemom nauki i kultury polonijnej: „Promocja kulturowo-informacyjna współczesnego wychodźstwa a dziedzictwo narodowe emigracji”" pod patronatem Jego Ekscelencji Tomasza Orłowskiego, Ambasadora Rzeczypospolitej Polskiej we Francji
}

\section{Paryż, 13-14 grudnia 2012 roku}

Organizatorem konferencji był Instytut Informacji Naukowej i Studiów Bibliologicznych, współorganizatorami: Stacja Naukowa PAN w Paryżu i Ministerstwo Spraw Zagranicznych RP. Konferencja odbywała się w Stacji Naukowej PAN w Paryżu. Była to już III Międzynarodowa Konferencja poświęcona dziedzictwu i problemom nauki i kultury polonijnej. Pierwsza odbyła się w 2009 roku w Henin-Beaumont, w północnej Francji, podejmując problematykę potrzeb informacyjnych w zakresie waloryzacji poloników, edukacji i kultury realizowanej na obczyźnie. Wskazano wówczas na brak analiz i badań z zakresu polonijnego dziedzictwa kulturowego w Europie i na świecie. Stąd w kwietniu 2011 roku odbyła się II Konferencja, dotycząca upowszechniania i promocji dorobku polonijnego we Francji. Jednym z istotnych problemów, jaki pojawił się podczas tej Konferencji, był problem kulturowo-informacyjnej dezintegracji środowisk polonijnych, dylematy wspólnego działania na rzecz ochrony bogactwa emigracyjnego dziedzictwa narodowego. Stąd decyzja o organizacji trzeciej Konferencji, której cele określili organizatorzy następująco:

- prezentacja wkładu polskiej (polonijnej) książki, nauki, sztuki, architektury we wspólne polsko-francuskie dziedzictwo europejskie,

- promocja polskiego dziedzictwa i kultury za granicą,

- próba zdefiniowania tożsamości współczesnej Polonii przez pryzmat jej dziedzictwa emigracyjnego,

- ukazanie integracyjnej roli kultury wychodźstwa oraz instytucji ją rozpowszechniających,

- ukazanie istoty komunikacji narodowej na obczyźnie i kreowanie paradygmatu solidarności kulturotwórczej poza krajem, 
- refleksja nad celowością dotychczas uprawianych i wyłaniających się nowych obszarów dotyczących promocji nauki, kultury, sztuki poza granicami kraju,

- dyskusja nad wizerunkiem polskiej historii i kultury, dziedzictwa narodowego.

Uczestników konferencji powitali: przedstawiciel Ambasadora RP we Francji oraz przedstawiciele Stacji Naukowej PAN w Paryżu. Konferencję otworzył profesor Dariusz Kuźmina, dyrektor Instytutu Informacji Naukowej i Studiów Bibliologicznych Uniwersytetu Warszawskiego. Zwrócił uwagę, że tworzenie zasobów cyfrowych we współczesnym świecie stało się zadaniem wiodącym dla środowisk pragnących zachować dziedzictwo narodowe swoich państw i narodów. Dla obecnej Polonii, rozsianej po wszystkich kontynentach, nieodzownym jest stworzenie platformy cyfrowej, na której będą gromadzone świadectwa działalności Polaków, którzy tworzyli i współtworzyli historię Polonii i państw, w których zamieszkali i stali się obywatelami. Instytut Informacji Naukowej i Studiów Bibliologicznych Uniwersytetu Warszawskiego realizuje projekt Dziedzictwo narodowe i kulturowe, polskie ślady za granica z Ministerstwa Spraw Zagranicznych i rozpoczął tworzenie Polonijnej Biblioteki Cyfrowej, w której będą publikowane dokumenty archiwalne, czasopisma i książki związane z działalnością Polonii. Wskazywał, że powodzenie działań warunkowane jest stworzeniem Federacji Bibliotek Cyfrowych, które mogłyby to, co zachowane (druki, listy, pamiętniki, pisma itp.) rejestrować, a następnie udostępniać w bibliotece cyfrowej.

W części pierwszej konferencji szczególne miejsce poświęcono takim instytucjom, jak: biblioteki, szkoły, katedry na uniwersytetach, Ośrodki Kultury Polskiej, stowarzyszenia, organizacje, fundacje itp. Następnie zwrócono uwagę na badanie zbiorów, dokumentowanie, polsko-francuskie przedsięwzięcia naukowe. Szczególne miejsce poświęcono problemom tożsamości, polityce edukacyjnej wobec mniejszości, promocji działalności Polaków i Polonii, działaniom w zakresie kultywowania dziedzictwa narodowego.

Dyrektor Biblioteki Polskiej w Paryżu, Danuta Dubois, przedstawiła historię Biblioteki w kontekście polskiego dziedzictwa kulturowego we Francji. Przybliżyła znaczenie ochrony pamięci zapisanej we wspomnieniach i dokumentach źródłowych, nakreśliła rozwój polskiego dziedzictwa intelektualnego, którego rozwój wspierała i umożliwiała Biblioteka Polska. Zwróciła uwagę, że jest to najstarsza Książnica poza krajem, świadectwo obecności Polaków na obczyźnie, ich wkładu w kulturę europejską. Dokonując refleksji 
nad współczesnym obrazem Książnicy, wskazała na funkcję upowszechniania kultury polskiej i europejskiej, wagę informacji w procesie integracji środowisk emigracyjnych, dialog z kulturą francuską poprzez liczne formy (spotkania, konferencje, koncerty, wystawy). Zwróciła uwagę na rolę tej instytucji w procesie konstruowania nowej Europy zauważającej i wspierającej inne kultury. Podkreśliła włączenie się, zainteresowanie i wsparcie Francuzów w procesie kultywowania dziedzictwa kulturowego Polaków. Obecnie Biblioteka upowszechnia kulturę polską i europejską, a wspiera ją między innymi Katedra Języka Polskiego z Uniwersytetu w Lille, gdzie zgromadzono około 15000 woluminów dotyczących literatury i historii Polski. Maryla Laurent w referacie Od zapomnianej biblioteki do zbioru dostępnego na catym świecie wskazała, że podjęte działania związane z uporządkowaniem zbiorów zostały uwieńczone sukcesem w postaci udostępnienia poloników online. Od czasu założenia w 1927 roku Katedra Języka Polskiego, gromadząc zbiory, była dostępna dla nauczycieli. Uporządkowano cenne zbiory, których istnienia nie odnotowano nigdzie w Europie.

Niniejsza problematyka była podejmowana przez innych referentów. Prezentowano zbiory rękopisów z XIX wieku zgromadzone w Bibliotece Polskiej w Paryżu, wskazywano na potrzeby i możliwości badawcze, omawiano ich wykorzystywanie w ostatnich latach. Podejmowano także istotną kwestę ich opracowania i dostępności, podkreślano konieczność ich ochrony i selektywnego udostępniania drogą internetową. Zwracano uwagę, że emigracja wymusza redefiniowanie wspólnej i indywidualnej historii i pamięci przez zderzenie z historią i pamięcią innego narodu. Stąd ma miejsce próba określania przynależności do obu kultur w wyniku ciągłej wymiany i zapożyczeń. Małgorzata Maria Grabczewska wskazywała, że w tworzeniu tej świadomości ważną rolę odgrywają dzieła malarskie, grafika, fotografia. Artyści polscy trafili do Francji już w XIX wieku i podejmowali tematy patriotyczne, wyrażając tym własne postawy, nadzieje i lęki. Powstało więc wiele autorskich kompozycji oraz reprodukcji. W referacie dokonano analizy wybranych artystów i ich dzieł, zwrócono uwagę na inicjatywy znaczących kolekcjonerów i mecenasów (książę Adam Czartoryski, rodzina Branickich, Adolf Cichowski). Podkreślono znaczenie fotografii, która poprzez swoją dostępność, czytelność i szybkość przekazu odegrała kluczową rolę w kształtowaniu grupowej i indywidualnej tożsamości polskich emigrantów.

Wojciech Sikora, kierujący Stowarzyszeniem „Instytut Literacki Kultura” Maisons-Laffitte, współpracowanik „Kultury” Jerzego Giedroycia, zwrócił 
uwagę na analogię między rolą Czartoryskiego, jako przywódcy obozu Hotel Lambert, a rolą Jerzego Giedrojcia, kierującego ośrodkiem w Maisons-Laffitte. Podjął próbę zauważenia i wskazania symboliki Wielkiej Emigracji, zwrócił uwagę, że Instytut Literacki był na mapie polskiego wychodźstwa specyficzny i wyjątkowy. W przeciwieństwie do większości emigracji politycznej i Polonii jego uwaga skierowana była głównie na Kraj i jego problemy, dodając woli życia i trwania Polakom, wspierając ważne dla trwania i rozwoju instytucje i osoby. W kolejnych wypowiedziach prezentowano problemy i perspektywy współpracy Stacji Naukowej PAN w Paryżu ze środowiskami polonijnymi w ostatnich latach. Katarzyna Seroka zwróciła uwagę na kontakty ze Stowarzyszeniem Inżynierów Techników Polskich we Francji, Stowarzyszeniem Architektów Polskich, Stowarzyszeniem Lekarzy Polskiego Pochodzenia, sekcją doktorantów Stowarzyszenia Studentów i Absolwentów Polskich. Małgorzata Pierrmatei-Zakrzewska przedstawiła dylematy nauczania języka polskiego w Ośrodku Kultury Polskiej na Sorbonie. Zwróciła uwagę, że w długiej, pięćdziesięcioletniej historii kursów języka polskiego na Sorbonie zmieniały się formy kształcenia i typ osób zainteresowanych naszym językiem. Początkowo byli to pracownicy naukowi z dziedziny nauk społecznych, współpracujący z polskimi uniwersytetami. W latach 80. XX wieku uczyło się języka polskiego prawie 250 cudzoziemców. Ostatnio obserwuje się spadek, stąd konieczne są zmiany w metodyce i dydaktyce kształcenia, nowe rozwiązania i działania motywujące do poznawana naszej kultury, w tym języka.

Andrzej Nieuważny z Uniwersytetu im. M. Kopernika w Toruniu w referacie Polsko-francuskie dziedzictwo historyczne z perspektywy ostatnich dwóch stuleci a budowa polonijnej/polskiej świadomości dziejowej. Nowe pola badawcze pytał: ile polskości we francuskości, poczynając od Napoleona, Kodeksu Napoleona. Prezentując wybrane fragmenty wspólnej historii, wzajemne oddziaływania kultury francuskiej i polskiej na przestrzeni dwóch stuleci, zaproponował nowe spojrzenie na problematykę wspólnego dziedzictwa europejskiego z perspektywy nie tylko jego ochrony, ale i rozwoju świadomości jego ustawicznego istnienia, jego istoty i potrzeby promocji.

W tym duchu prezentowane były inne referaty, w których zwracano uwagę na wspólne dziedzictwo archeologiczne (Bartłomiej Sz. Szmoniewski, Polsko-francuskie dziedzictwo archeologiczne dotyczace badań $i$ wspólnych przedsięwzięć naukowych) czy dziedzictwo naukowe (Piotr Daszkiewicz, Dziedzictwo naukowe Wtadystawa Taczanowskiego - wktad polskiej emigracji dla poznania 
fauny neotropikalnej). Liczni polscy emigranci, zwłaszcza we Francji i Peru, uczestniczyli w badaniach południowoamerykańskiej fauny. Wydana w Renes praca na temat ornitologii w Peru jest jedną z najważniejszych przyrodniczych prac. Dzięki przyrodnikom emigrantom można mówić o „złotym okresie” polskiej ornitologii. Polscy uchodźcy polityczni stali się pionierami peruwiańskiej nauki. To dziedzictwo naukowe stało się impulsem dla dalszych badań na temat bioróżnorodności, ekologii i innych nauk przyrodniczych XXI wieku.

Alicja Zawadzka, dziennikarka, fotograf, reżyserka filmów dokumentalnych i spektakli teatralnych, przedstawiła postać Florentyna Trawińskiego, zbawcę Luwru. Legenda głosi, że uczestnicząc w Komunie Paryskiej, wbrew woli komunardów, potajemnie uratował Luwr przed spaleniem. W referacie przedstawiono bogatą biografię syna powstańca styczniowego, który wraz z ojcem i bratem schronił się w Paryżu przed represjami carskimi. Wychowanek Szkoły Polskiej, zaangażowany w środowisku polskiej emigracji i jej stowarzyszeń, promował polską kulturę, literaturę i sztukę w ówczesnych francuskich encyklopediach, prasie i wydawnictwach polskich. Kawaler Legii Honorowej, ceniony pracownik Luwru w latach 1872-1906, poliglota nagradzany wielokrotnie przez Akademię Francuską, wiele wniósł do europejskiego muzealnictwa.

Szczególne miejsce zajął problem ochrony i udostępniania zbiorów od czasów Wielkiej Emigracji, dokumentacji związanej z założeniem pierwszej szkoły w 1842 roku (170-lecie jej powołania, na co zwróciłem także uwagę w swoim wystąpieniu), przykładu szkoły otwartej, przeciwstawiającej się gettoizacji narodowej. Iwona H. Pugacewicz w referacie Szkoła polska w świetle dokumentów Archiwum Narodowego Francji sięgnęła do źródeł dotyczących Szkoły Narodowej Polskiej w Paryżu zgromadzonych w Archiwum Narodowym Francji. Zaprezentowała obraz polskiej szkoły widziany oczami władz francuskich, ukazała rolę władz francuskich w procesie powstawania i rozwoju polskiej szkoły w kontekście merytorycznym, ekonomicznym i politycznym. Zwróciła uwagę na interesujące dokumenty w postaci skarg i donosów napływających do francuskich ministerstw zajmujących się funkcjonowaniem szkół. Takie spojrzenie na polskie dziedzictwo edukacyjne, szkołę narodową w Paryżu w kontekście obcych źródeł pozwala nam mieć pełny obraz tamtego okresu. Pugacewicz w znanych mi pracach już wcześniej przedstawiła powstanie i działalność polskiej szkoły w Batignolles ${ }^{1}$.

1 Szerzej nt. temat: I. H. Pugacewicz: Szkoła narodowa polska na Batignolles. Obraz edukacji dwukulturowej w dziewiętnastowiecznym wymiarze historycznym. 
W historii Polski problem utrzymania i wspierania rozwoju tożsamości narodowej zawsze należał do bardzo istotnych, szczególnie w przypadku Polaków żyjących poza granicami kraju. $Z$ analizy źródeł wynika, że zorganizowaną działalność w tym zakresie zapoczątkowała Wielka Emigracja powstała w wyniku rozbiorów i wykreślenia Polski z mapy Europy przez trzy mocarstwa. Jak wskazuje Pugacewicz, przywołując sprawozdanie Towarzystwa Wychowania Narodowego Dzieci Wychodźców Polskich, pierwszą szkołę dla synów emigrantów powstańców listopadowych założono w 1842 roku. Usytuowano ją w podparyskiej wówczas osadzie Batignolles (szkoła batignolska). Powołanie tej polskiej szkoły w 1842 roku stanowiło pierwszy krok ku edukacji międzykulturowej (wychowaniu międzykulturowemu). Polska emigracja polistopadowa była świadoma wagi patriotycznej edukacji narodowej, świadoma niszczącej narodowość polską polityki zaborców, jak też świadoma potrzeby edukacji w kontekście wiary we francuski postęp kulturowo-cywilizacyjny, w idee oświeceniowe wolności narodów, idee demokracji. Wskazuję na ten fakt, odwołując się do analiz i badań Pugacewicz, gdyż stwierdziłem, że idee towarzyszące powołaniu, funkcjonowaniu, jak też likwidacji w 1969 roku, a następnie reaktywacji tej szkoły, były i są znane wśród Polaków rozsianych na globie ziemskim, w tym na Litwie, Ukrainie, w Białorusi, Kazachstanie, czy nawet w Buriacji, na co zwróciłem uwagę w swoim wystąpieniu i podczas prowadzenia jednej z sesji konferencji. Sądzę, że była i jest ona przykładem dla innych w zakresie kultywowania specyficznej, romantycznej tradycji niepodległościowej i jednocześnie kreowania otwartej tożsamości, otwartej na Innego i jego kulturę z zachowaniem wartości i dziedzictwa kultury polskiej. Jestem przekonany, że można powiedzieć, że była wzorem odniesienia dla innych tego typu szkół, które powstawały, funkcjonowały i upadały w czasie stu siedemdziesięciu lat od jej powołania. Podkreśliłem, że spotykając się na tej konferencji w Paryżu, winniśmy oddać

W: T. Lewowicki, A. Różańska, G. Piechaczek-Ogierman (red.): Wielokulturowość i problemy edukacji. Cieszyn - Warszawa - Toruń 2012, Wydział Etnologii i Nauk o Edukacji Uniwersytetu Śląskiego, WSP ZNP w Warszawie, Stowarzyszenie Wspierania Edukacji Międzykulturowej, Wydawnictwo Adam Marszałek, s. 201-225, taż: Stan, perspektywy i problemy szkolnictwa z polskim językiem nauczania we Francji. W: T. Lewowicki, J. Nikitorowicz, A. Szczurek-Boruta (red.): Szkolnictwo z polskim językiem nauczania w państwach europejskich - stan, problemy i perspektywy. Białystok - Cieszyn - Warszawa 2010, Uniwersytet w Białymstoku, Wydział Etnologii i Nauk o Edukacji Uniwersytetu Śląskiego, Wyższa Szkoła Pedagogiczna ZNP w Warszawie, Stowarzyszenie Wspierania Edukacji Międzykulturowej, s. 283-329. 
hołd założycielom i wielu pokoleniom realizatorów tej szkoły. Była ona przykładem przeciwstawiania się gettoizacji narodowej, na co w edukacji międzykulturowej zwracamy obecnie szczególną uwagę, uznając ten nurt jako najbardziej istotny w procesie kultywowania kultury narodowej.

Po odzyskaniu niepodległości w 1918 roku koordynatorem w zakresie kultywowania dziedzictwa narodowego emigracji był Światowy Związek Polaków z Zagranicy „Światpol”, na czele którego stał marszałek Senatu Rzeczypospolitej Polskiej. Sądzę, że tradycje te są kontynuowane. Aktualnie funkcjonuje Ośrodek Rozwoju Polskiej Edukacji za Granicą. W strukturze polskojęzycznej edukacji są:

- społeczne szkoły niedzielne i sobotnie o najdłuższych tradycjach, które działają przy polskich parafiach,

- szkoły należące do systemów edukacji innych państw, gdzie nauczanie prowadzone jest w języku polskim (szkoły polskie z językiem wykładowym oraz szkoły, w których nauczanie języka polskiego ma miejsce jako nauczanie języka ojczystego lub obcego).

Uważam, że świadomość narodowa zawsze towarzyszyła emigrantom, którzy z różnych powodów znaleźli się poza pierwszą, daną naturalnie, ojczyzną. Nie chcąc dopuścić do wynarodowienia dzieci urodzonych na obczyźnie (w drugiej ojczyźnie), w pierwszej kolejności starali się zachować język. $\mathrm{Z}$ drugiej strony zastanawiali się nad perspektywami życia i realizowania się w nowej ojczyźnie i podejmowali próby równoległego, podwojonego funkcjonowania w jednej i w drugiej kulturze, wskazywali na potrzebę większego wysiłku i trudu, aby nie rezygnować z polskości i jednocześnie realizować się w obywatelskości w nowym kraju. Zdawali sobie sprawę z przydatności edukacji i wykształcenia bez względu na to, gdzie będą żyć, mieli świadomość lojalności wobec dziedzictwa przeszłości i otwarcia na rozwój - perspektywy przyszłości w nowym miejscu.

Do tego typu myślenia, czyli równoległego funkcjonowania w dwóch Ojczyznach, świadomości podwojonej, lojalności wobec odziedziczonej naturalnie i nowej, mniej lub bardziej wybranej Ojczyzny, nawiązywałem ustawicznie, promując idee i zadania edukacji międzykulturowej, realizując w praktyce wsparcie polskojęzycznym obywatelom Białorusi i Litwy (Uniwersytet w Białymstoku od 1993 roku prowadzi studia dla polskojęzycznych obywateli Białorusi, a od 2007 roku w Wilnie utworzył filię (Wydział zamiejscowy UwB).

W przygotowanym na niniejszą konferencję tekście Problemy tożsamościowe Polaków, obywateli państw powstałych po rozpadzie ZSRR. Polacy na 
Litwie, Białorusi, w Kazachstanie, w Buriacji zwróciłem uwagę na złożony i dynamiczny problem tożsamości. Zauważyłem i wskazałem na wielość typów kreowania się tożsamości Polaków w kilku krajach (tożsamość podwojona, rozproszona, rozszczepiona z różnymi zestawami narodowościowymi, etniczno-narodowościowymi i narodowościowo-obywatelskimi. Odwołując się do prowadzonych od wielu lat badań na pograniczu polsko-litewsko-białoruskim, wskazałem, że pewnych zjawisk, w tym szczególnie zjawiska tożsamości, nie dostrzega się i nie analizuje, gdy nie przysparzają problemów. Zauważa się je, skupia się na nich uwagę szczególnie wówczas, gdy zatracają jasność, gubią się w warunkach zmiany, takiej na przykład, jak powstawanie wolnych, niezależnych państw po rozpadzie ZSRR. Zachodzące procesy w tych krajach stawiają jednostkom, grupom i całym społeczeństwom nowe wyzwania, powodując między innymi ustawiczne pytania o to, kim jestem, kim się staję, kim chciałbym być, kim warto, powinienem, wprowadzając często w stan dyskomfortu i frustracji. Coraz większej liczbie ludzi nie udaje się sprostać nowym wyzwaniom, wielu okazuje zobojętnienie, rezygnując z aktywności i twórczych działań, generując demony, lęki, kompleksy, wzniecając ustawicznie wojnę polsko-polską, polsko-rosyjską, polsko-niemiecką. Zwróciłem także uwagę na złożony problem kształtowania się tożsamości w kontekście odwoływania się i funkcjonowania świadomościowego, poznawczego i terytorialnego w kilku Ojczyznach, w wyniku emigracji i deportacji (Ojczyznach chcianych-wybieranych i niechcianych-narzucanych).

Problemy tożsamości były kontynuowane w innych wystąpieniach na konferencji. Między innymi Monika Salmon-Siama, pracownik Uniwersytetu w Lille, autorka prac na temat symboli religijnych i kultu bohaterów narodowych w procesie kształtowania się tożsamości kulturowej, interesująca się mitami wspólnotowymi i międzypokoleniową transmisją wśród polskiej emigracji we Francji, opierając się na wybranych przykładach polskich sztandarów polonijnych, zwróciła uwagę na symbolikę patriotyczno-religijną będącą spoiwem tożsamościowym francuskiej Polonii. Problemem jest zanik i zapominanie tych wartości, które były trwałym nośnikiem tożsamościowym. Brak istotnego spoiwa dawnej wspólnoty polonijnej zmusza nas do zastanowienia się nad ewolucją postaw wspólnotowych.

Elżbiet Łątka w referacie List jako prośba o pomoc. Listy emigrantek polskich pisane we Francji w dwudziestoleciu międzywojennym przedstawiała indywidualne historie Polek pracujących na wsi, we Francji w ramach umowy. Są to listy odnalezione w archiwum w Tours, adresowane do inspektorki. 
Zachowane przez nią stanowią obecnie pisane świadectwo historii młodych Polek pracujących na wsi ponad siły, mówiące o wykorzystywaniu seksualnym i ekonomicznym. Nie mając możliwości porozumienia się z zatrudniającymi je gospodarzami, podejmowały trud napisania i wysłania listu z rozpaczliwym wołaniem o pomoc w trudnej, upokarzającej sytuacji. Były to listy pisane na skrawkach papieru, pisane bardzo prostym, ubogim językiem, z błędami ortograficznymi, lecz silnie nasycone przeżyciami i emocjami.

Jak wskazywałem wyżej, jedna z sesji podczas konferencji była poświęcona problemom tożsamości. Sławomir Czarlewski, były konsul generalny RP w Lyonie, ambasador RP w Brukseli, prawnik i politolog, w referacie Polonia francuska i belgijska na poczatku XXI wieku - problem z definicja i tożsamościa podkreślił, że na przełomie XX i XXI wieku rozpoczęły się głębokie zmiany w samodefiniowaniu się i tożsamości grupowej w europejskich środowiskach polonijnych. Ten proces trwa, a przyczyn zmian jest i było wiele, między innymi związanych z odzyskaniem suwerenności, wolnorynkowym systemem demokratycznym, mobilnością ludności itp. Wskazywał, że Polacy we Francji czy Belgii zakładali małe firmy i grupowali się wokół pracodawców, sami się organizowali, nie czekając na pomoc rządu polskiego, integrowali się z nową Ojczyzną w kontekście pracy. Czarlewski, pełniąc misję dyplomaty we Francji i w Belgii, będąc wcześniej emigrantem, z pewnością lepiej rozumie i interpretuje zachodzące zmiany związane z podmiotowością, emancypacją, podwojoną tożsamością, dylematami tożsamościowymi Polaków. Obecnie wielu przedefiniowuje związki z krajem pochodzenia i z krajem osiedlenia, będąc w procesie trwającej integracji europejskiej. Istotne wnioski i działania winny wynikać dla polskiego rządu, polskich instytucji zajmujących się i wspierających Polonię w kultywowaniu dziedzictwa kulturowego. Jest więc potrzeba wypracowania nowych kierunków, w jakich mogłaby funkcjonować i rozwijać się działalność polonijnych organizacji pozarządowych.

Krystyna Kalińska, wieloletni konsul generalny w Strasburgu i w Lille, znawca Polonii i jej historii w okręgu Nord-Pas-de-Calais, kontynuowała wątek podjęty przez Czarlewskiego. Zwróciła uwagę, że Polonia w północnej Francji wywodzi się z kilku fal emigracji XX wieku, z których największym było wychodźstwo zarobkowe okresu międzywojennego, a także powojenna emigracja polityczna. Pierwsze fale emigracji to polscy emigranci z kopalń w Westfalii i Nadrenii, następnie Polacy spod zaboru rosyjskiego, austriackiego i pruskiego. „Kolonie” polskie tworzące się w tym regionie już w latach 1908/09 przez wiele lat żyły prawie w całkowitej izolacji od społeczności 
francuskich. Proces akulturacji i - w efekcie - w wielu przypadkach asymilacji rozpoczął się w kolejnych pokoleniach w latach, poczynając od lat 60 . XX wieku w wyniku rezygnacji z odrębnego szkolnictwa, pracy, małżeństw mieszanych. Obecnie wnuki i prawnuki pierwszych emigrantów są Francuzami polskiego pochodzenia. Kalińska podkreśliła, że społeczność francuska zauważała i wielokrotnie uznawała wkład Polaków, obywateli francuskich polskiego pochodzenia w rozwój regionu północnej Francji. Stąd bycie jednoczesne Polakiem i Francuzem to proces zachodzący przez realizację aspiracji, proces trudny i złożony, który ukazała na przykładzie jednej z rodzin.

Problem tożsamości podjęła także w swoim referacie Jolanta Tatara, dyrektor Szkoły im. Jana Pawła II w Lemont I Romeoville: Stanowa polityka edukacyjna wobec mniejszości etnicznych a efekty edukacyjne polskich uczniów w dystrykcie chicagowskim. Wskazała, że amerykańskie Biuro Statystyczne (US Census Buremu) podaje, że 3\% Amerykanów, czyli prawie 9 milionów, posiada w swoim dziedzictwie kulturowym korzenie polskie. Jednakże tylko 7\% z nich, czyli ponad 600 tysięcy, używa na co dzień języka polskiego. Zwracała więc uwagę, podobnie jak Kalińska, na proces asymilacji językowej, utraty najcenniejszego elementu dziedzictwa narodowego. Pytała więc: czy i jak można temu zapobiegać, czy warto podtrzymywać znajomość języka polskiego wśród dzieci polskich imigrantów? Próbując odpowiadać - zwracała uwagę na rolę polskiej sobotniej szkoły języka polskiego w podtrzymywaniu znajomości języka polskiego wśród kolejnych pokoleń. Prezentowała także własne wyniki badań z tego zakresu prowadzone w szkole publicznej Chicago Public School wśród uczniów dwujęzycznych. Podkreśliła, że państwo, które otwiera drzwi dla emigrantów, nie może sobie pozwolić na ich zamknięcie dla dzieci przybyszów. Analizując strategie państw przyjmujących, zwróciła uwagę na rezygnację z asymilacji i dominowanie nauczania dwujęzycznego z otwarciem na inne kultury. Podkreśliła także rosnące znaczenie kultur etnicznych w programach kształcenia szkół państwowych, gdzie w 680 szkołach dystryktu chicagowskiego uczniowie posługują się 133 językami.

W końcowej części obrad zaprezentowano działania związane z tworzeniem zasobów cyfrowych w celu zachowania dziedzictwa narodowego współczesnej Polonii rozsianej na całym globie ziemskim. Dariusz Kuźmina, dyrektor Instytutu Informacji Naukowej i Studiów Bibliologicznych, przedstawił realizację projektu w zakresie tworzenia Polonijnej Biblioteki Cyfrowej. Wskazał na przykład digitalizacji zbiorów Józefa Obrębskiego, ucznia Mali- 
nowskiego i Znanieckiego, którego prace znane są w wielu krajach. Między innymi badał i opisał kulturę Jamajki, a archiwum dotyczące jego dokonań naukowych znajduje się w Stanach Zjednoczonych Ameryki Północnej. Przedstawił także podjęte działania w zakresie digitalizacji polskich badaczy w Peru. Anna Kamler, wicedyrektor niniejszego Instytutu, przedstawiła program studiów i omówiła przedmioty traktujące o instytucjach polonijnych na świecie oraz nową ścieżkę studiów magisterskich „Dziedzictwo kulturowe". Z kolei Anna Mierzecka, adiunkt w tymże Instytucie, w referacie Źródta informacji elektronicznej zwiqzane $z$ tematykq emigracyjna przedstawiła problem pozyskiwania informacji z wykorzystywaniem źródeł dostępnych w sieci. Te kanały informacyjne są szczególnie przydatne w sytuacji, kiedy pozyskiwane informacje pochodzą ze źródeł, które w rzeczywistości są znacznie oddalone w przestrzeni od odbiorców, tak jak jest to w przypadku społeczności emigracyjnych.

Ksiądz Piotr Szot, doktor nauk teologicznych, wicerektor Polskiej Misji Katolickiej we Francji, przedstawił historię i wkład Polskiej Misji Katolickiej w polskie dziedzictwo narodowe we Francji. Zauważył, że ludzie świeccy należący do Wielkiej Emigracji przyczynili się do jej powstania w 1836 roku. Przypomniał słowa Adama Mickiewicza: Na katolicyzmie trzeba budować więź z Ojczyzną. Zwrócił uwagę, że polonijna działalność kulturalna, edukacyjna, humanitarna, kombatancka, artystyczna, a także naukowa często wiązana była z działalnością polskich ośrodków duszpasterskich w Paryżu i na terenie całej Francji.

Grażyna Wrona, profesor Instytutu Bibliotekoznawstwa i Informacji Naukowej Uniwersytetu Pedagogicznego im. KEN w Krakowie, wspólnie z Edytą Wygonik-Barzyk, doktorantką w tym Instytucie, zaprezentowała prasę polską w Irlandii po akcesji Polski do UE w roku 2004. W przedstawionym referacie rozwinęły i udokumentowały hasło tytułu: informować, promować, wspierać. Masowy napływ Polaków na Zieloną Wyspę, Polaków nieznających kraju przyjmującego, jego realiów, bardzo często języka, zwyczajów, kultury, powodował konieczność zdobycia niezbędnych informacji w zakresie poszukiwania pracy, załatwiania formalności, poznawania nowego kraju, jego kultury i tradycji. Jednak w Irlandii, gdzie dotychczasowa Polonia była bardzo nieliczna, nie funkcjonowały żadne polonijne media ani instytucje, które mogłyby sprostać tym wyzwaniom informacyjnym. Tak więc stworzono kanały przepływu informacji poprzez prasę (pojawiło się aż kilkanaście tytułów). Oprócz typowych funkcji informacyjnych gazety promowały Polskę, 
jej kulturę, język, tradycje oraz wspierały ważne dla funkcjonowania polskiej społeczności inicjatywy. Występowano z wieloma inicjatywami współpracy polsko-irlandzkiej, a redakcje stały się miejscami gdzie szukamy pomocy, porad, pośrednictwa, a dziennikarz i wydawcy stali się swoistą „elitą” polskiej społeczności.

Magdalena Szkuta, kustosz polskich zbiorów w British Library w Londynie, przedstawiła w swoim referacie Rola prasy emigracyjnej $w$ integracji wychodźstwa polskiego w krajach Europy Zachodniej 1945-1989 historię prasy emigracyjnej i jej znaczenie dla dorobku wychodźstwa polskiego. Wśród licznych wydawnictw prasowych szczególną uwagę poświęciła takim pismom jak: „Dziennik Polski”, „Dziennik Żołnierza”, „Wiadomości”, „Orzeł Biały” i „Kultura”. Zwróciła uwagę, że w kontekście utrzymania poczucia tożsamości narodowej na obczyźnie istotne było życie intelektualne emigracji, powoływane i funkcjonujące instytucje społeczno-polityczne, naukowe i artystyczne.

W kontekście powyższego sądzę, że dobrze się stało, że Ministerstwo Edukacji Narodowej opracowało na lata 2009-2011 Program Rozwoju Oświaty Polskiej za Granicą i Oświaty Polonijnej. W efekcie zauważono szanse i zagrożenia, potrzebę wsparcia szkół polonijnych procesie kultywowania dziedzictwa kulturowego.

Konferencja odbywała się przed świętami Bożego Narodzenia, stąd przypomniano opis wigilii Bożego Narodzenia dokonany przez najstarszą córkę Adama Mickiewicza, Marię (Marynię). W swoich Wspomnieniach opowiedzianych najmtodszemu bratu Józefowi tak opisuje wigilię Bożego Narodzenia w mieszkaniu na Batignolles, rue du Boulevard 14, w latach 1845-1846: „Zwyczaj kucyj i święconego ściśle był u nas zachowywany, szczególnie kucya, na którą też przypadały ojca imieniny. Dzień ten u nas najsolenniejszy w roku, w takie mnie wprawiał wzruszenie, że noc całą przepędzałam prawie w gorączce. Rano szliśmy wszyscy razem ojcu winszować, składać nasze życzenia i podarki: później zaczynała się długa procesya przyjaciół i znajomych, która przez dzień cały trwała bez przystanku. Wieczorem na stole sianem zasłanym, ukazywała się kucya, na nitce spuszczonej u sufitu, wisiała gwiazdka z opłatka i kolebka, które ojciec sam przygotował, i przesuwały się, z wielką nieraz trudnością pod dozorem mamy sporządzone tradycyjne potrawy. W ostatnich latach, z wielką satysfakcją ojca, znalazła się nawet żydówka polska, która przychodziła ugotować szczupaka po żydowsku... W każdą wigilię także, wieczorem dawała się nagle słyszeć za drzwiami kolęda: W żłobie leży, któż pobieżny, której ojciec z widocznem rozrzewnieniem słuchał, półgło- 
sem wtórując ulubionej pieśni, która w nas tyle wspomnień budziła. Byli to przyjaciele i znajomi, którzy zawsze z tą samą, a zawsze miłą występowali niespodzianką. Ojciec dopiero otwierał im drzwi i sam ich śpiewowi przewodniczył. Wieczór kończył się ponczem, a jak było więcej gości i ożywienia, tańcami i polonezem, w których ojciec występował, zawsze powtarzając, że to jedyny taniec tak piękny, poważny dla każdego wieku stosowny. Nieraz przytem wspominał, że w pierwszych czasach emigracji prowadził czasem w polonezie starą Wirtemberską, która od tego tańca nie wymawiała się. Zasypialiśmy z myślą rozmarzoną temi pieśniami, wspomnieniami krajowemi, żałując tylko, że tak niezmierzony przeciąg czasu, rok cały, oddzielał nas od drugiej podobnej uroczystości". 